\title{
HPLC Determination of Metformin, Famotidine and Ranitidine by Derivatization with Benzoin from Drugs and Biological Samples
}

Malik Alamgir $^{1^{*}}$, Muhammad Yar Khuhawar ${ }^{1}$, Saima Qayoom Memon ${ }^{2}$, Amir Hayat ${ }^{1}$, Rizwan Ali Zounr ${ }^{1}$ and Asma Chanar ${ }^{1}$

${ }^{1}$ Institute of Advanced Research Studies in Chemical Sciences, University of Sindh, Jamshoro, Pakistan.

${ }^{2}$ Institute of Chemistry, University of Sindh, Jamshoro, Pakistan.

"Corresponding author: Malik Alamgir, Institute of Advanced Research Studies in Chemical Sciences, University of Sindh, Jamshoro, Pakistan, Tel: +92 3465092589; Email: aalam012@gmail.com

Received date: March 29, 2017; Accepted date: May 11, 2017; Published date: May 15, 2017

Copyright: () 2017 Alamgir M, et al. This is an open-access article distributed under the terms of the Creative Commons Attribution License, which permits unrestricted use, distribution, and reproduction in any medium, provided the original author and source are credited.

\begin{abstract}
A novel High Performance Liquid Chromatography (HPLC) method has been developed based on pre column derivatization with benzoin for determination of metformin, famotidine and ranitidine. The separation was achieved from $\mathrm{C} 18$ column when eluted isocratically, the solution of the drugs with methanol, water, acetonitrile and Tetra Hydrofuran (THF) (40:40:16:4 v/v) with a flow rate at $1 \mathrm{~mL} / \mathrm{min}$. UV detection was found to be $268 \mathrm{~nm}$. Linear calibrations range was obtained with $2.5-12.5 \mu \mathrm{g} / \mathrm{ml}$, with limits of detection (LODs) $0.091-0.30 \mu \mathrm{g} / \mathrm{ml}$. The total run time for elution was $3.5 \mathrm{~min}$. The derivitization, separation and quantitation was repeatable $(n=4)$ in terms of retention time and peak height/peak area with relative standard deviation (RSD) within $0.84-1.55 \%$ and $0.68-1.17 \%$ respectively.

The method was applied for the analysis of metformin, famotidine and ranitidine from pharmaceutical preparations, human serum and human urine. The possible interfering effects of the sample matrix were checked by the analysis by standard addition method and matrix effect was not indicated.
\end{abstract}

Keywords: High Performance Liquid Chromatography (HPLC); Metformin; Famotidine; Ranitidine; Derivatization; Benzoin

\section{Introduction}

The guanidine compounds are characterized by the presence of guanidine functional group. These are compounds with a carbon surrounded by three amino functions. The hydrogen atom of the amino function may be substituted [1]. These are basic compounds and many of these are present in biological fluids and in tissues at low concentration in human and animals [2]. Metformin (N,Ndimethylguanidine) (Figure 1) is used as an oral antihyperglycemic drug in the management of non- insulin dependent diabetes mellitus $[3,4]$. However high concentration of metformin in plasma has been associated with an increase in the incidence of lactic acidosis, particularly in patient in acute renal failures [5,6]. It is slowly and incompletely absorbed from gastrointestinal tract and in excreted unchanged in urine [7].

Famotidine,

(3-(((2-((aminoiminomethyl)amino)-4-thiazoyl)methyl)thio)-N-(aminosulfonyl)propanimidamide) (Figure 1) is a potent competitive and reversible inhibitor of histamine action at $\mathrm{H} 2$ receptors and is used for the treatment of active duodenal ulcer, gastric ulcer, heartburn, acid indigestion, sour stomach and Zollinger-Ellison syndrome $[8,9]$. The famotidine is commonly given to the patients [10].

Ranitidine $\mathrm{HCl}, \quad \mathrm{N}-(2-[(5-$ dimethylaminomethyl)furan-2-yl) methylthio] ethyl)-N-methyl-2-nitroethene-1,1-diamine $\mathrm{HCl}$ (RAN) (Figure 1) is an inhibitor of gastric acid secretion that is used in the treatment of gastric and duodenal ulcers. It competitively inhibits the action of histamine on the $\mathrm{H} 2$ receptors of parietal cells [11]. There are many analytical methods that have been reported for the analyses of these important drugs. Metformin has been determined by spectrophotometer and High Performance Liquid Chromatography (HPLC) [12-19]. Famotidine by spectrophotometry, spectrofluorimetry, voltammetric, potentiometric, flow injection analysis, HPLC and Capillary Zone Electrophoresis (CZE). Ranitidine by spectrophotometry, polarography Cyclic Voltammetry (CV), potentiometric sensors, the flow injection analysis. HPLC, CZE and Gas Chromatography (GC) [20-45]. The physicians prescribe famotidine or ranitidine together with the metformin for the treatment of duodenal ulcer to the diabetic patients. Kai et al. [45] reported that gunidino compounds react with benzoin to give single product 2substituted amino-4,5-diphemyl imidazole ring. Metformin and famotidine are pharmaceutical products containing gunadino functional group and were examined for pre column derivatization with benzoin followed by HPLC separation and UV detection. Ohta et al. [46] reported HPLC determination of metformin using benzoin as derivatizing agent. Alamgir et al. reported spectrophotometric and spectroflurometric procedures for the determination of famotidine in pharmaceutical preparation and biological fluids by derivatization with benzoin from drug and biological samples $[21,22]$. Ranitidine does not contain typical guandino functional group (A carbon atom surrounded by three amino functions) but contain a carbon attached to the two amino functions. The ranitidine react with benzoin to form derivative. The present work examines the reaction of ranitidine with benzoin for the simultaneous HPLC separation and determination of metformin, famotidine and ranitidine by pre column derivatization with benzoin from drugs and biological samples. 


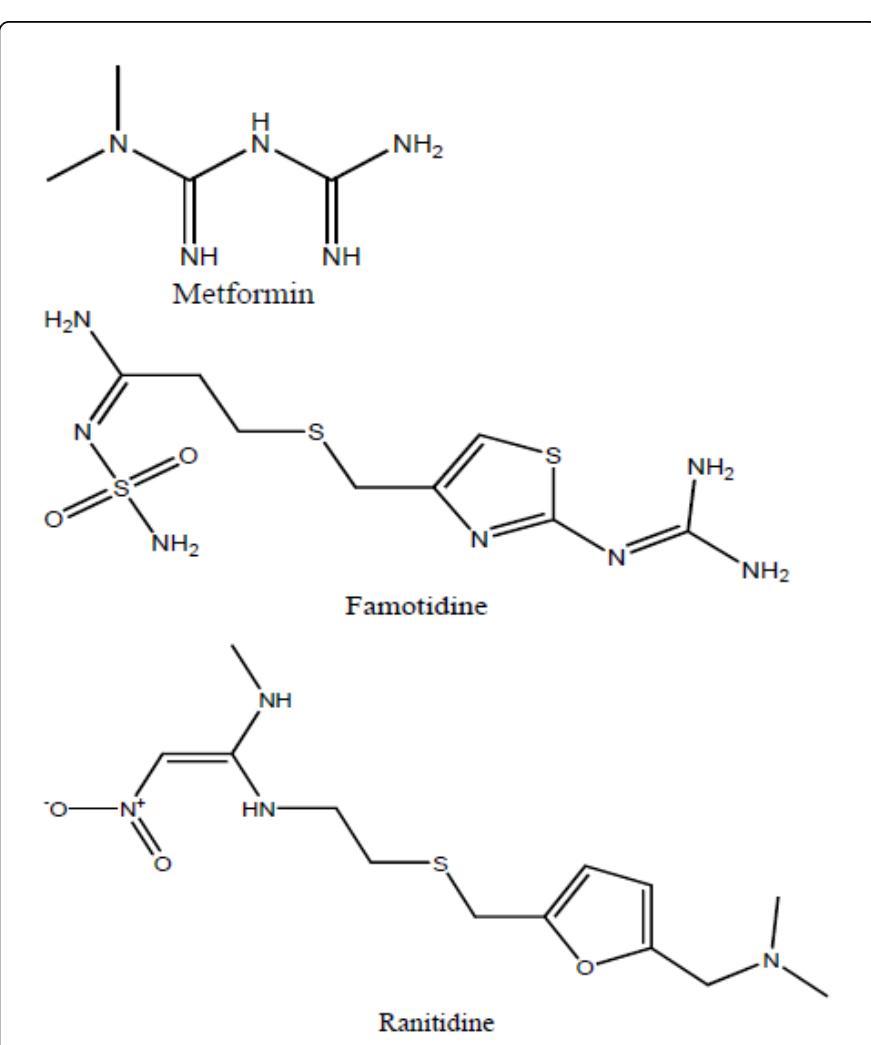

Figure 1: Structural diagrams of Metformin, Famotidine and Ranitidine.

\section{Experimental}

\section{Chemicals and solutions}

All the chemicals used were of G.R or analytical grade, freshly prepared deionized distilled water was used throughout the study. Metformin, famotidine and ranitidine (Sigma, Buchs, Switzerland), benzoin (Fluka, Buchs, Switzerland), and methanol (RDH Chemical Spring Valley, CA, USA) were used. The stock solution $(1 \mathrm{mg} / \mathrm{ml})$ was prepared by dissolving appropriate amount of drug in methanol and further dilution were carried out in deionized water. G.R grade Hydrochloric Acid ( $\mathrm{HCl} 37 \%$ ), potassium chloride, acetic acid, sodium acetate, ammonium acetate, sodium tetraborate, boric acid, sodium bicarbonate, sodium carbonate, ammonium chloride, ammonia solution and sodium hydroxide were purchased from E-Merck Darmstadt, Germany. Buffer solution (0.1 M) between $\mathrm{pH} 1$ and 10 at unit interval were prepared from the following; hydrochloric acidpotassium chloride ( $\mathrm{pH} 1-2)$, acetic acid-sodium acetate $(\mathrm{pH} 3-6)$, ammonium acetate $(\mathrm{pH} 7)$, boric acid-sodium tetraborate $(\mathrm{pH}$ 7.5-8.5), sodium bicarbonate- sodium carbonate ( $\mathrm{pH} \mathrm{9)}$, ammonium chloride-ammonia solution ( $\mathrm{pH} 10)$.

\section{Equipment}

The $\mathrm{pH}$ measurements were made with an Orian $420 \mathrm{~A} \mathrm{pH}$ meter (Orion Research Inc. Boston, USA) with combined glass electrode and reference internal electrode. Spectrophotometric study was carried out with double beam Perkin Elmer Lambda 35 (Perkin Elmer, Singapore), spectrophotometer with dual $1 \mathrm{~cm}$ silica cuvettes. The spectrophotometer was controlled by computer with Lambda 35 software. Mass spectrometry of ranitidine-benzoin derivative was recorded at HEJ Research Institute of Chemistry on Jeol IMS 600 mass spectrometer. Chromatographic studies were carried out on an Agilent HPLC system 1100 series (Agilent Technology USA) equipped with G1300A LC pump, G1315B diode array detector and 7725 Rhedyne injector. Data was obtained by the computer with Chemstation data acquisation software. Reverse phase LC was performed isocratically at room temperature using column Phenomenex C18, $5 \mu \mathrm{m}(150 \times 4.6$ $\mathrm{mm}$ id) throughout the study.

\section{Preparation of ranitidine-benzoin derivative}

Ranitidine $(0.001 \mathrm{M})$ dissolved in methanol $(10 \mathrm{ml})$ was added benzoin $(0.001 \mathrm{M})$ dissolved in methanol $(15 \mathrm{ml})$. A few drops of potassium hydroxide $(2 \mathrm{M})$ were then added and content were reflexed for $30 \mathrm{~min}$. Half of the solvent was distilled off and remaining solution was cooled at $4^{\circ} \mathrm{C}$ overnight. The precipitate obtained was filtered and recrystallized from methanol (Melting point $248 \pm 2^{\circ} \mathrm{C}$ ). Mass spectrum shows $\mathrm{M}+$ relative intensity $525(1 \%)$.

\section{Spectrophotometric procedure}

In $5 \mathrm{ml}$ volumetric flask was transferred solution containing 0.5-2.5 $\mathrm{ml}$ of $25 \mu \mathrm{g} / \mathrm{ml}$ metformin, famotidine or ranitidine separately. Each was added $0.6 \mathrm{ml}$ benzoin solution ( $8 \mathrm{mmole}), 0.5 \mathrm{ml}(2 \mathrm{M})$ potassium hydroxide, $0.5 \mathrm{ml}$ of 2-merecaptoethanol $(8 \mathrm{mmole})$ and $0.5 \mathrm{ml}(0.2$ $\mathrm{mmol}$ ) sodium thiosulphate. The content were heated at water bath at $70-80^{\circ} \mathrm{C}$ for $10 \mathrm{~min}$. and allowed to cool at room temperature $\left(30^{\circ} \mathrm{C}\right)$. Then added sodium tetraborate buffer $1 \mathrm{~mL}(0.1 \mathrm{M}) \mathrm{pH}$ 8.5. The volume was made to $5 \mathrm{~mL}$ with methanol. The absorption spectra of the solutions were recorded against reagent blank within 450-200 nm.

\section{HPLC procedure}

An aqueous solution containing metformin, famotidine and ranitidine within the final concentration range from $2.5-12.0 \mu \mathrm{g} / \mathrm{ml}$ each was placed in $5 \mathrm{~mL}$ volumetric flask and spectrophotometric procedure was followed. The solution $20 \mu \mathrm{L}$ was injected on column Phenomenex C18, $5 \mu \mathrm{m}(150 \times 4.6 \mathrm{~mm}$ id $)$ and eluted isocratically with methanol-water- acetonitrile and $\operatorname{THF}(40: 40: 16: 4 \mathrm{v} / \mathrm{v})$ mobile phase with a flow rate of $1 \mathrm{~mL}$ min-1. UV detection was at $268 \mathrm{~nm}$.

\section{Analysis of metformin, famotidine and ranitidine in pharmaceutical preparations}

Five tablets from each for Metformin tablets Glucophage (Merck, Pvt., Ltd. Quetta, Pakistan), Metphage ((Efroze Chemical Industries (Pvt.) Ltd Karachi, Pakistan). Neodipar (Sanofi Korangi Industrial Area Karachi-74900) collected from local market (Hyderabad, Sindh) were weighed and ground to fine powder. Similarly five tablets of each Ulfam (Focus \& Rulz Pharmaceuticals Pvt. Ltd., Islamabad, Pakistan), Femim (Batala Pharmaceuticals, Gujranwala, Pakistan), Famotin (Efroze, Korangi Industrial Area, Karachi, Pakistan) and Facid (Matador Chemicals, Lahore, Pakistan), for famotidine. Zentac (Glax Smith Kiln Pakistan Limited Karachi), Reneph (Epharm Laboratories, Marriot Road, Karachi) for ranitidine were treated as above for metformin tablets. The powder of $(0.10 \mathrm{~g})$ of a tablet was weighed and dissolved in methanol and water $(1: 1 \mathrm{v} / \mathrm{v})$. The solution was filtered through Whatman filter paper 42 and volume was adjusted to $100 \mathrm{ml}$ in volumetric flask. The solution containing the active ingredient 
within the calibration range of each drug was taken and HPLC procedure was followed.

The quantitation was made from the calibration curve based on linear regression equation " $y=a x+b$ " prepared from standard solution of metformin, famotidine and ranitidine. The drugs in the pharmaceutical preparations were also examined by the standard addition technique. Two solutions $(1.0 \mathrm{ml}$ each) prepared from a pharmaceutical preparations were transferred to $5 \mathrm{ml}$ volumetric flasks. A solution was added standard of active ingredient corresponding to $1.25 \mu \mathrm{g} / \mathrm{ml}$ metformin, $3.75 \mu \mathrm{g} / \mathrm{ml}$ famotidine and $5.0 \mu \mathrm{g} / \mathrm{ml}$ ranitidine. Both the solutions were processed as HPLC procedure. The quantitation was made from an increase of response with added standard.

\section{Analysis of metformin, famotidine and ranitidine from spiked deproteinized serum and urine}

Blood sample $(5 \mathrm{ml})$ and urine sample $(5 \mathrm{ml})$ collected from healthy volunteers who had not taken any medicine during a proceeding week were incubated at $30^{\circ} \mathrm{C}$ for $1 \mathrm{~h}$. and centrifuged at $3000 \mathrm{~g}$ for $15 \mathrm{~min}$. The supernatant layer was collected and was added twice the volume (5 $\mathrm{ml}$ ) of methanol. The contents were again centrifuged at $3000 \mathrm{~g}$ for 15 min. The supernatant layer was collected. Solution $(1 \mathrm{~mL})$ was transferred to a $5 \mathrm{~mL}$ volumetric flask, and was added metformin, famotidine and ranitidine corresponding to 4 and $7 \mu \mathrm{g} / \mathrm{ml}$ at final concentration. The liquid chromatographic procedure was then followed. The quantification was carried out from linear regression equation " $y=a x+b$ " derived from external calibration curve. A solution of deproteinized serum $(1 \mathrm{ml})$ was transferred to $5 \mathrm{ml}$ volumetric flask and was not added any drug and was processed as HPLC procedure and was treated as blank.

The blood samples from healthy volunteers (employee and students of Institute of Advance Research Studies in Chemical Sciences University of Sindh Jamshoro Pakistan) were collected in EDTA tubes by vein puncture with a disposable syringe. Morning urine samples of healthy volunteers were collected in clean plastic bottles. The volunteers taking part in the study were informed about the aim and objectives of the study and verbal consent to participate in the project was obtained. The volunteers informed that they did not take medicine during at least one preceding week.

\section{Results and Discussion}

Metformin and famotidine are reported to react with the benzoin to form derivative $[21,22,46]$. The reaction of the benzoin toward ranitidine was examined. Pure benzoin-ranitidine derivative was prepared by refluxing together methanol solution of benzoin and ranitidine in alkaline medium. The precipitate isolated was used to record mass-spectrum of the derivative and indicates $\mathrm{M}+$ Mass corresponding to spectrum at $\mathrm{m} / \mathrm{z} 525$ followed by a loss of $-\mathrm{CH}_{3}$ with peak at 510 . The base peak was observed at $207(100 \%)$, beside these peaks, other peaks were appeared as $429,355,281,73$ and 44 which support the formation of derivative and its fragmentation pattern (Figure 2).

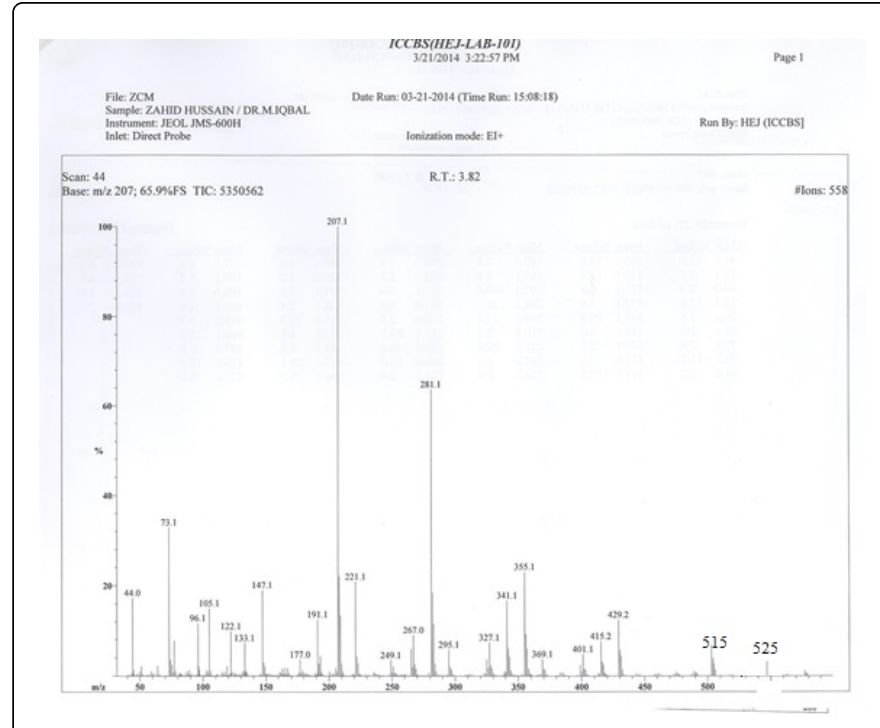

Figure 2: Mass spectrum of expected derivative.

Attempt was made to elute and separate benzoin derivatives of metformin, famotidine and ranitidine from HPLC column Phenomenex C-18, $5 \mu \mathrm{m}(150 \mathrm{~cm} \times 4.6 \mathrm{~mm}$ id $)$ using simple isocratic modes. Different solvent systems with their different compositions were tried, and complete separation with symmetrical peaks were obtained when eluted with methanol- water- acetonitrile and tetrahydrofuran (40: 40: 16: $4 \mathrm{v} / \mathrm{v}$ ) with a flow rate of $1 \mathrm{ml} / \mathrm{min}$. UV detection was at $268 \mathrm{~nm}$. The derivatization conditions of ranitidine with benzoin were examined in terms of concentration of derivatizing reagent potassium hydroxide, 2-merecaptoethanol, and sodium thiosulphate added for each determination. Heating time and temperature and final addition of buffer solution for $\mathrm{pH}$ adjustment were also optimized. The conditions which gave maximum response were considered as optimum. A similar condition as reported for famotidine was observed as reported [21,22].

\section{Quantitation}

The optimized HPLC conditions for elution and separation of metformin, famotidine and ranitidine were used to draw linear calibration curve for the drug by plotting average peak height/peak area $(n=4)$ against concentration and linear response were obtained with $2.5-12.5 \mu \mathrm{g} / \mathrm{ml}$ with coefficient of determination(r2) within 0.997-0.993 (Table 1).

The limit of detection and limit of quantitation were measured as signal to noise ratio (3:1) and (10:1) and were obtained with 0.091-0.30 $\mu \mathrm{g} / \mathrm{ml}$ and $0.30-1.01 \mu \mathrm{g} / \mathrm{ml}$ respectively (Table 1 ). The separation and quantitation were repeatable in terms of retention time and peak height/peak area with relative standard deviation (RSD) within $2.8 \%$.

The repeatability of the analytical procedure inter day $(n=4)$ and intraday $(\mathrm{n}=4)$ was examined at the final concentration of $5.0 \mu \mathrm{g} / \mathrm{ml}$ and $7.50 \mu \mathrm{g} / \mathrm{ml}$ of each drug by the same operation for the analysis of drug mixture on different and same day and RSD were obtained within $4.0 \%$ (Table 1). 
Citation: $\quad$ Alamgir M, Khuhawar MY, Memon SQ, Hayat A, Zounr RA, et al. (2017) HPLC Determination of Metformin, Famotidine and Ranitidine by Derivatization with Benzoin from Drugs and Biological Samples. Pharm Anal Acta 8: 546. doi:10.4172/2153-2435.1000546

Page 4 of 7

\begin{tabular}{|c|c|c|c|c|c|c|}
\hline S. No. & Drug & Calibration range ( $\mu \mathrm{g} / \mathrm{ml})$ & $\begin{array}{l}\text { LOD } \\
(\mu \mathrm{g} / \mathrm{ml})\end{array}$ & $\begin{array}{l}\mathrm{LOQ} \\
(\mu \mathrm{g} / \mathrm{ml})\end{array}$ & $\begin{array}{l}\text { Coefficient } \\
\text { determination }(r 2)\end{array}$ of & Linear regression equation \\
\hline 1 & Metformin & $2.50-12.50$ & 0.1 & 0.3 & 0.997 & $Y=0.8817 x+0.0643$ \\
\hline 2 & Famotidine & $2.50-12.50$ & 0.3 & 0.8 & 0.995 & $Y=0.767 x+0.1048$ \\
\hline 3 & Ranitidine & $2.50-12.50$ & 0.091 & 1.01 & 0.993 & $Y=1.1293 x+0.0029$ \\
\hline
\end{tabular}

Table 1: Analytical parameters for the HPLC of drugs.

\section{Sample analysis}

The pharmaceutical preparations Metphage, Glucophage (500 mg tablet) and Glucophage (250 mg tablet) for metformin Ulfam, Fermim, Famotin, Facid acid for famotidine, Zentac and Reneph for ranitidine were analysed following the procedure for the analysis of pharmaceutical preparations. The results of analysis were agreed with the labelled values by manufacturer with the relative deviation within 0.44-5.5\% The RSD for replicate analysis $(n=4)$ were obtained within $0.15-5.5 \%$. The test mixture $(n=4)$ within the calibration range were analysed for the simultaneous determination of the drugs and relative error was obtained within $\pm 3.8 \%$ as shown in Table 2 .

\begin{tabular}{|c|c|c|c|c|c|c|c|}
\hline S. No. & Drug & Brand name & $\begin{array}{l}\text { Amount labeled in } \mathrm{mg} / \\
\text { tablet }\end{array}$ & $\begin{array}{l}\text { Amount found in } \mathrm{mg} / \\
\text { tablet }\end{array}$ & $\begin{array}{ll}\% & \text { age } \\
\text { recovery }\end{array}$ & Relative Deviation\% & RSD $\% n=4$ \\
\hline \multirow{3}{*}{1} & \multirow{3}{*}{ Metformin } & Metphage & 850 & 846.3 & 99.56 & 0.44 & 0.15 \\
\hline & & Glucophage & 500 & 495.9 & 99.18 & 0.82 & 0.16 \\
\hline & & Glucophage & 250 & 247.5 & 99.04 & 0.96 & 0.16 \\
\hline \multirow{3}{*}{2} & \multirow{3}{*}{ Famotidine } & Ulfam & 40 & 38.6 & 96.5 & 3.5 & 5.2 \\
\hline & & Femme & 40 & 38.8 & 97 & 3 & 1.7 \\
\hline & & Famotin & 20 & 18.9 & 94.5 & 5.5 & 2.8 \\
\hline \multirow{3}{*}{3} & \multirow{3}{*}{ Ranitidine } & Famocid & 40 & 38.5 & 96.25 & 3.75 & 1.2 \\
\hline & & Zentac & 150 & 148.27 & 98.84 & 0.72 & 2.7 \\
\hline & & Reneph & 150 & 147.6 & 98.4 & 1.6 & 0.82 \\
\hline
\end{tabular}

Table 2: Analysis of Metformin, Famotidine and Ranitidine in Pharmaceutical Preparations.

The pharmaceutical additives methylparabin, propylparabin, gum acacia, lactose, fructose, glucose, sodium chloride, lauryl sulphate, and ascorbic acid were added at twice the concentration drug and analysis was carried out flowing analytical procedures. These additives did not affect the determination with relative error within $\pm 4.0 \%$ when compared with same concentration of standard drug without addition of the pharmaceutical additives.

The analysis of pharmaceutical preparations was further conformed by standard addition. The pharmaceutical were processed as analysis of pharmaceutical preparation and were appropriately diluted to bring the concentration within the calibration range for metformin, famotidine and ranitidine. Each of the pharmaceutical preparations were spiked with corresponding to drug at the concentration of 1.25 $\mu \mathrm{g} / \mathrm{ml}$ metformin, $3.75 \mu \mathrm{g} / \mathrm{ml}$ famotidine and $5.0 \mu \mathrm{g} / \mathrm{ml}$ ranitidine. The derivatization and chromatographic elution was carried out as analytical procedure. The quantitation of the results indicate an agreement with the observed value by linear calibration and recovery of drug from pharmaceutical were calculated within $97.53-99.70 \%$ as shown in Figure 3 and Table 3.

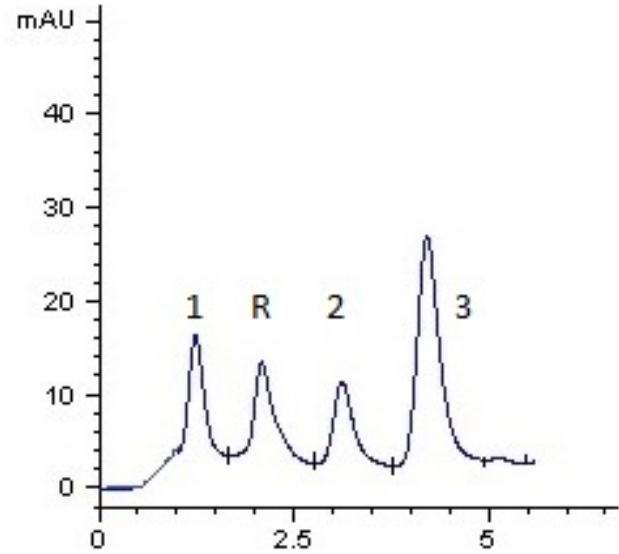

Figure 3: HPLC separation of standards Metformin (1), Benzoin (reagent), Famotidine (2), Ranitidine (3) and Benzoin reagent (R). 
Citation: $\quad$ Alamgir M, Khuhawar MY, Memon SQ, Hayat A, Zounr RA, et al. (2017) HPLC Determination of Metformin, Famotidine and Ranitidine by Derivatization with Benzoin from Drugs and Biological Samples. Pharm Anal Acta 8: 546. doi:10.4172/2153-2435.1000546

Page 5 of 7

\begin{tabular}{|c|c|c|c|c|c|c|c|}
\hline S. No. & Drug & Sample & $\begin{array}{l}\text { Amount of standard added } \\
\mu \mathrm{g} / \mathrm{ml}\end{array}$ & $\begin{array}{l}\text { Amount found } \\
\text { in } \mu \mathrm{g} / \mathrm{ml}\end{array}$ & \%age recovery & Relative error\% & RSD $\% n=4$ \\
\hline \multirow[t]{4}{*}{1} & Metformin & Serum & 2.5 & 2.48 & 99.2 & 0.8 & 0.62 \\
\hline & & & 5 & 4.92 & 98.4 & 0.6 & 1.4 \\
\hline & & urine & 2.5 & 2.45 & 99.18 & 0.82 & 2.18 \\
\hline & & & 5 & 4.96 & 99.2 & 1.8 & 2.1 \\
\hline \multirow[t]{4}{*}{2} & Famotidine & Serum & 2.5 & 2.47 & 96.5 & 3.5 & 3.55 \\
\hline & & & 5 & 4.93 & 98.6 & 1.4 & 2.15 \\
\hline & & urine & 2.5 & 2.47 & 97 & 3 & 0.54 \\
\hline & & & 5 & 4.94 & 98.8 & 1.2 & 1.6 \\
\hline \multirow[t]{4}{*}{3} & Ranitidine & Serum & 2.5 & 2.46 & 98.84 & 0.72 & 0.78 \\
\hline & & & 5 & 4.92 & 98.4 & 1.6 & 0.65 \\
\hline & & Urine & 2.5 & 2.48 & 98.4 & 1.6 & 3.28 \\
\hline & & & 5 & 4.95 & 99.1 & 0.9 & 1.25 \\
\hline
\end{tabular}

Table 3: Analysis of metformin, famotidine and ranitidine from spiked deproteinized serum and urine.

The blood and urine samples of healthy volunteers who had not taken any medicine at least one preceding week were deproteinized with methanol. An aliquot $(1 \mathrm{ml})$ of deproteinized blood and urine samples were added standard solution within calibration range and processed as analytical procedure. The amount found agreed with the spiked values with relative error within \pm 0.60 -3.50 and RSD of the replicate analysis $(n=3)$ was within $3.5 \%$ and recovery was calculated 96.50-99.20\% (Figure 4 and Table 4,5).

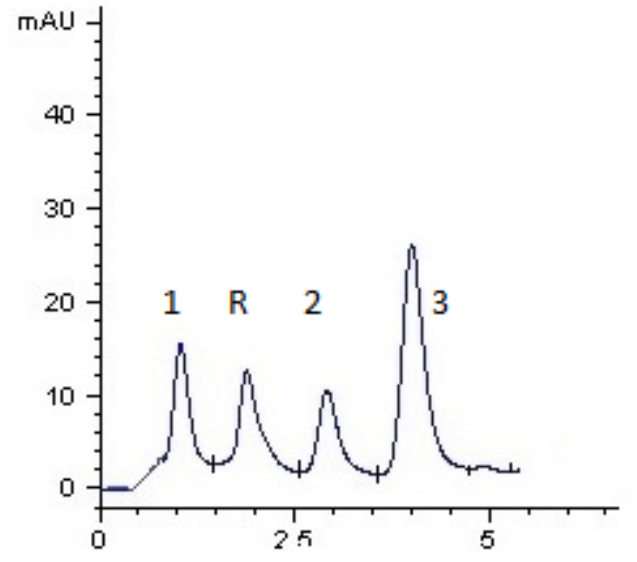

Figure 4: HPLC separation of standards Metformin (1), Benzoin (reagent), Famotidine (2), Ranitidine (3) and Benzoin reagent (R).

\begin{tabular}{|c|c|c|c|c|c|c|c|}
\hline S. No. & Con. taken $\mu \mathrm{g} / \mathrm{ml}$ & Con. added $\mu \mathrm{g} / \mathrm{ml}$ & Height in $\mathrm{mV}$ & $\begin{array}{l}\text { Total Amount in } \\
\mu \mathrm{g} / \mathrm{ml}\end{array}$ & Amount found in $\mu \mathrm{g} / \mathrm{ml}$ & $\begin{array}{l}\text { \%age } \\
\text { Found }\end{array}$ & RSD $\% n=4$ \\
\hline 1 & Metformin 6.25 & 1.25 & 44.43 & 7.50 & 7.40 & 98.67 & 1.40 \\
\hline 3 & Famotidine 6.25 & 3.75 & 59.37 & 10.00 & 9.97 & 99.70 & 2.20 \\
\hline 4 & Ranitidine 6.25 & 5.0 & 65.12 & 11.25 & 10.98 & 97.53 & 1.28 \\
\hline
\end{tabular}


Table 4: Standard addition method for metformin famotidine and ranitidine.

\begin{tabular}{|c|c|c|c|c|}
\hline $\begin{array}{c}\text { Amount } \\
\text { taken }\end{array}$ & \multicolumn{2}{|c|}{ Inter-day } & \multicolumn{2}{c|}{ Intra-day } \\
\hline Conc. $\mathbf{\mu g} / \mathrm{ml}$ & $\begin{array}{c}\text { Height in } \\
\mathrm{mV}\end{array}$ & RSD\% $\mathrm{n}=4$ & Height in $\mathrm{mV}$ & RSD\% $\mathrm{n}=4$ \\
\hline Metformin 2.5 & 68.54 & 3.2 & 67.9 & 0.98 \\
\hline $\begin{array}{c}\text { Famotidine } \\
\mathbf{2 . 5}\end{array}$ & 72.92 & 3.92 & 71.68 & 1.2 \\
\hline Ranitidine 2.5 & 81.25 & 2.96 & 82.45 & 3.4 \\
\hline
\end{tabular}

11. Kumar MK, Jayasagar G, Chandrasekhar K, Ashok T, Rao YM (2003) Validated HPLC method for the determination of ranitidine in human serum and its application in a clinical pharmacokinetic study. Die Pharmazie 58: 284- 285.

12. Alamgir M, Muhammad MY, Hayat A, Majidano AA (2014) Spectrophotometric Determination of Metformin in Pharmaceutical Preparations. Serum and Urine using Benzoin as Derivatizing Reagent. J Chem Soc Pak 36: 2.

13. Hassan SSM, Mahmoud WH, Elmosallamy MAF, Othman AHM (1999) Determination of metformin in pharmaceutical preparations using potentiometry spectrofluorimetry and UV-visible spectrophotometry. Acta Chimica Acta 378: 299-311.

Table 5: Analysis of inter day and intera day variation of Metformin, Famotidine and Ranitidine solutions.

\section{Conclusion}

An analytical procedure has been developed for HPLC determination of metformin, famotidine and ranitidine after derivatization with benzoin. The limits of detection were observed within $0.091-0.30 \mu \mathrm{g} / \mathrm{ml}$. The method was applied for the analysis of pharmaceutical preparations and spiked deproteinized blood and urine samples with RSD within $0.44-5.50 \%$. The observed values agreed with labelled and spiked amount with relative deviations within $0.60-3.50 \%$.

\section{Acknowledgment}

This work was supported by Higher Educational commission of Pakistan under the indigenous fellowship phase ii.

\section{References}

1. Marescan B, Deshmukh DR, Kockx M, Possemies, Qureshi IA, et al. (1992) Guuanidino compounds in serum, urine, liver kidney and brain of man and some ureoltic animals. Metabolism 41: 526-532.

2. Kandhro AJ, Khuhawar MY (2013) Hplc Determination of Guanidino Compounds in Serum of Uremic Patients Using Methylglyoxal As Derivatizing Reagent. J Liq Chrom Related Tech 36: 2279-2291.

3. Al-Shamaony L, Al-Khazraji SM, Twaiji HA (1994) Hypoglycemic effect of Artemisia herba alba II. Effect of a valuable extract on some blood parameters in diabetic animals. J Ethnopharmacol 43: 167-171.

4. Johansen K (1999) Efficacy of metformin in the treatment of NIDDM. Meta-analysis. Diabetes Care 22: 33-37.

5. Bristol-Myers Squibb Company (1995) Glucophage (metformin hydrochloride) tablets product monograph. Bristol-Myers Squibb Company. Priceton, NJ, USA.

6. Abu ZA, Shubietah R, Badah G (1999) Extractional-spectrophotometric determination of famotidine in pharmaceutical formulations. J Pharm Biomed Anal 21: 459-465.

7. Zhang L, Yeh KC (1998) Determination of famotidine in human plasma by high performance liquid chromatography with column switching. J Pharm Biomed Anal 16: 1051-1057.

8. Raynolds JEF, Martindale (1999) The extra pharmacopeia (23rd edn). The Pharmaceutical Press. Massachusetts.

9. Reynolds JEF, Martindale (1996) The extra pharmacopoeia (31st edn.). The Pharmaceutical Press. London pp: 1231-1237.

10. Sasaki M, Sudoh T, Fujimura A (2005) Pharmacokinetics of ranitidine and nizatidine in very elderly patients. Am J Ther 12: 223-225.

14. Mistri HN, Jangid AG, Shrivastav PS (2007) Liquid chromatography tandemmass spectrometry method for simultaneous determination of antidiabetic drugs metformin and glyburide in human plasma. J Pharm Biomed Anal 45: 97-106.

15. Zarghi A, Foroutan SM, Shafaati A, Khoddam A (2003) Rapid determination of metformin in human plasma using ion-pair HPLC. J Pharm Biomed Anal 31: 197-200.

16. Arayne MS, Sultana N, Zuberi MH (2006) Development and validation of RPHPLC method for the analysis of metformin. (2006) Pak J Pharm Sci 19: 231-235.

17. Al-Rimawi F (2009) Development and validation of an analytical method for metformin hydrochloride and its related compound (1cyanoguanidine) in tablet formulations by HPLC-UV. Talanta 79: 1368-1371.

18. Deepti J, Surendra J, Deepak J, Maulik A (2008) Simultaneous Estimation of Metformin Hydrochloride, Pioglitazone Hydrochloride and Glimepiride by RP-HPLC in Tablet Formulation. J Chromatogr Sci 46: 501-504.

19. Cheng CL, Chou CH (2001) Determination of metformin in human plasma by high-performance liquid chromatography with spectrophotometric detection. J Chromatogr B Biomed Sci Appl 762: 51-58.

20. Rahaman N, Kashif M (2003) Application of ninhydrin to spectrophotometric determination of famotidine in drug formulations. IL Farmaco 58: 1045-1050.

21. Alamgir M, Muhammad MY, Hayat A, Majidano AA (2013) Spectrophotometric determination of famotidine using benzoin as derivatizing agent. Int J Adv Res 8: 549-555.

22. Alamgir M, Muhammad MY, Saima Q, Hayat A, Rizwan AZ (2015) Spectrofluorimetric analysis of famotidine in pharmaceutical preparations and biological fluids by derivatization with benzoin. Spectrochimica Acta Part A: Molecular and Biomolecular Spectroscopy 134: 449-452.

23. David IG, Popa DE (2016) Voltammetric determination of famotidine on a disposable pencil graphite electrode. Turk J Chem 40: 125-135.

24. Amin AS, Shama SA, Ahmed IS, Gouda EA (2002) Spectrophotometric determination of famotidine through oxidation with nbromosuccinimide and cerric sulphate. Anal Lett 35: 1851-1862.

25. Paraskevas DT, Aspasia V, Theodora B (2006) Optimization and validation of a dissolution test for Famotidine tablets using flow injection analysis. J Pharmaceut Biomed Anal 41: 437-441.

26. Novakovic J (1999) High-performance thin-layer chromatography for the determination of ranitidine hydrochloride and famotidine in pharmaceuticals. J Chromatogr A 846: 193-198.

27. Diane AIA, Rajesh P, Abdul WB (2007) Simple and universal HPLC-UV method to determine cimetidine. ranitidine. famotidine and nizatidine in urine: Application to the analysis of ranitidine and its metabolites in human volunteers. J Chromat B 860: 235-240. 
Citation: $\quad$ Alamgir M, Khuhawar MY, Memon SQ, Hayat A, Zounr RA, et al. (2017) HPLC Determination of Metformin, Famotidine and Ranitidine by Derivatization with Benzoin from Drugs and Biological Samples. Pharm Anal Acta 8: 546. doi:10.4172/2153-2435.1000546

Page 7 of 7

28. Zhong L, Yeh KC (1998) Determination of famotidine in human plasma by high performance liquid chromatography with column switching. J Pharm Biomed Anal 16: 1051-1057.

29. Husain S, Khalid S, Nagaraju V, Rao NR (1996) High-performance liquid chromatographic separation and determination of small amounts of process impurities of famotidine in bulk drugs and formulations. J Chromat A 743: 328-334.

30. Campanero MA, Bueno I, Arangoa MA, Escolar M, Quetglas EG (2001) Improved selectivity in detection of polar basic drugs by liquid chromatography-electrospray ionization mass spectrometry: Illustration using an assay method for the determination of famotidine in human plasma. J Chromatogr B 763: 21-33.

31. Helali N, Tran NT, Monser L, Taverna M (2008) Capillary zone electrophoresis method for the determination of famotidine and related impurities in pharmaceuticals. Talanta 74: 694-698.

32. Basavaiah K, Nagegowd P (2004) Determination of ranitidine hydrochloride in pharmaceutical preparations by titrimetry and visible spectrophotometry using bromate and acid dyes. IL Farmaco 59: 147-153.

33. Kokoletsi MX, Kafkala S, Tsiaganis M (2005) Simultaneous determination of cimetidine. famotidine. nizatidine. and ranitidine in tablets by capillary zone electrophoresis. J Pharm Biomed Anal 38: 763-767.

34. Agarwal YK, Shivaramachandra K, Rao GN (1992) Spectrophotometric determination of famotidine in pharmaceutical preparations. J Pharm Biomed Anal 10: 521-549.

35. Orsine EMD, Martins JLS (1993) Determination of Ranitidine Hydrochloride in Pharmaceutical Preparations by Ultraviolet and Visible Spectrophotometry. Anal Lett 26: 1933-1941.

36. Richter P, Toral MI, Muñoz-Vargas F (1994) Polarographic behaviour and determination of ranitidine in pharmaceutical formulations and urine. Analyst 119: 1371-1374.

37. Toma R, Carmen M (2001) Flow-injection extraction-spectrophotometric method for the determination of ranitidine in pharmaceutical preparations. J Pharma Biomed Anal 26: 609-615.
38. Norouzi P, Ganjali MR, Daneshgar P (2007) A novel method for fast determination of Ranitidine in its pharmaceutical formulations by fast continuous cyclic voltammetry. J Pharmaco Toxico Method 55: 289-296.

39. Neil WB, Benjamin JH, Simon WL (1999) Determination of Ranitidine and Salbutamol by Flow Injection Analysis with Chemiluminescence Detection. Analytica Chimica Acta 384: 151-158.

40. Dragica Z, Stafilov T (2003) Development of an HPLC method for the determination ofranitidine and cimetidine in human plasma following SPE. J Pharma Biomed Anal 33: 165-173.

41. Lopezeroz C, Vinas P, Campillo N, Hemandezcordoba M (1994) A novel gradient HPLC method for simultaneous determination of ranitidine. methylparaben and propylparaben in oral liquid pharmaceutical formulation. Analyst 121: 1043-1046.

42. Zendelovska D, Stafilov T (2003) Development of an HPLC method for the determination of ranitidine and cimetidine in human plasma following SPE. J Pharama Biomed Anal 33: 165-173.

43. Gao Y, Tian Y, Sun X, Yin XB, Xiangm QMG, et al. (2006) Determination of ranitidine in urine by capillary zone electrochemiluminescent detection. J Chromatogr B 832: 236-240.

44. Majidano SA, Khuhawar MY (2012) GC determination of famotidine: ranitidine, cimetidine and metformin in pharmaceutical preparations and serum using methylglyoxal as derivatizing reagent. Chromatographia 75 : 1311-1317.

45. Kai M, Miyazaki T, Yamaguchi M, Ohkura Y (1983) High performance liquid chromatography of guanidine compounds using benzoin as a precolumn fluorescent derivatization reagent J Chromatogra 268: 417-424.

46. Ohta M, Iwasaki M, Kai M, Ohkura Y (1993) Determination of a Biguanide. Metformin. by High-Performance Liquid Chromatography with Precolumn Fluorescence Derivatization. Anal Sci 9: 217-220. 